\title{
Self-Development Potential for Progressive Work
}

\author{
Phrakrukosolpariyattayanukij (Tharueti Rungchaiwitoon) ${ }^{1}$, Phrasuwanmahaphuthaphibal (Ho \\ Subhaddo) ${ }^{2}$, Phrakrusoponpattaravet (Ittipol Padhãniko) ${ }^{3}$, Suddhipong Srivichai ${ }^{4}$ \\ 1,2,3,4Faculty of Education, Mahachulalongkornrajavidyalaya University \\ ${ }^{1}$ konkuandee@gmail.com, ${ }^{2}$ howattrimitr@gmail.com, ${ }^{3}$ oodwatsaymai@gmail.com, ${ }^{4}$ suddhipong.sri@hotmail.com
}

\begin{abstract}
It is possible to develop ourselves to advance our career and collective work, even though self-improvement is very difficult. So, for the purpose of human resource development, the article identified the keys to personal development, based on the philosophy of VETS, namely V = Vision is the vision of the organization in the future, which is derived from wisdom, ideas, possible and consistent with goals and organizational obligations, $\mathrm{E}=$ Education is a method of human resource development that is necessary in one way because it increases the qualifications of human resources to have more knowledge due to technological changes adaptations, $\mathrm{T}=$ Training is to increase the knowledge, expertise, ability and change the attitudes, attitudes, feelings of the participants, $\mathrm{S}=$ Study tour is an activity that will help us to do the best practice. Study tour has many advantages, example, it helps to observe the business in other departments, their office operations, process of working, etc. These symbols should be in conjunction with the principle of path of accomplishment; basis for success (Iddhipada IV), consisting of 1) Chanta (satisfaction) is satisfaction or motivation, 2) Viriya (intention) is the indomitable intention, 3) Chitta (concentration) is a mind focused on work, 4) Wimangsa (check) is the use of intelligence to contemplate, contemplate, inspect, reason and examine even more slack, defect or failure, etc. in a business that has been known, tried, and thought to find solutions to improve. Following these principles will lead human being to develop their skills in working for oneself or for others to get a better life or to achieve the target goals of their organizations. Finally, achieving these goals will lead to one's happiness and ultimately will result to a successful and prosperous organization.
\end{abstract}

Keywords

Self-Development, Potential, Progressive Work

Article Received: 10 August 2020, Revised: 25 October 2020, Accepted: 18 November 2020

\section{Introduction}

Self-improvement is where a person tries to change himself for achieving a better life. This can be achieved through behavioral change in response to the needs, motives or goals of oneself, and also to develop one's own potential, physically, mentally, emotionally and socially in order to become an effective member of society. Self-improvement is important to one's self for achieving a peaceful life and beneficial to the society or to the organization to which a person belongs. Therefore, development of self is an essential requisite for human society and for the success of an organization. It is an important and valuable tool for an organization all success in this age of competition. Thus, it is imperative for an organization to have a policy and plan that focus on personal development.

\section{The Basic Concept of Self-Development}

A person to develop himself must be committed to change or improve oneself. This will help to promote selfdevelopment. Key concepts of self-development are as follows: [1]

1. All human beings have their own valuable potential. So, it is possible to train and develop themselves in every matter.

2. As no person is perfect in every aspect, it is essential for oneself to develop more and more.

3. Even if a person knows himself best, he or she cannot adjust themselves in some areas. He or she cannot survive alone as he or she still need the help of others to develop themselves. Therefore, controlling one's own thoughts, feelings, and actions are important in controlling the external environment.

4. The main obstacle to self-improvement and development lies to the individuals because if they refuse to change their way of thinking and acting. Then, they are refusing to create new habits or practice new skills which are necessary for themselves.

5. Self-improvement and development can be performed at any time and can be improved continuously when encountering problems or shortcomings about themselves.

\section{The Importance of Personal Development}

Mission for each department in society, all societies require human resources to perform the task. Everyone has developed and improved himself to keep up with the working style or technology of the society. Development of techniques or new ways of thinking and skills are needed to improve performance and quality of individual-output. This helps neighboring agency to compete more qualitatively and efficiently with other societies, thus resulting in the overall economic stability of a country.

\section{Benefits of Personal Development in the Profession}

At work, no matter what kind of career, an individual must be adaptable and flexible to achieve a successful career. This can be achieved with due consideration of their own interests and social responsibilities. Thus, self-development is very essential in building up a career. The benefits of self- 
development in Myanmar in Northeastern Thailand are as follows: [3]

1. Improve knowledge and ability.

2. It helps to be confident.

3. Improve work efficiency.

4. Respect the professional society.

5. Assist in the progress of the work.

6. Lead to creative work.

Along personal development, it is essential to develop and enhance human relationships in every aspect, including occupation: [4]

1. Feelings that they have goals in life. People have to develop themselves to have goals in life, to have the future and to have hope by believing that he can develop himself. Therefore, there is a need to improve and change oneself in every aspect to have a better life.

2. Should possess a feeling of courage to interact well with others, people must develop themselves to have a feeling of courage and should have a strong determination to interact with others, and to help in building good interpersonal relationships.

3. Feeling open and humble, individuals must develop themselves to possess the necessary personal qualities by having a sincere feeling, open and be humble, to help in building good interpersonal relationships.

4. Feelings of faith and stability, a person must develop himself to have the personal qualities necessary, that is, to have faith in oneself. This will cause a feeling of pride in ourselves that we are one too. If we do good deeds, be diligent and patient, our life will be better, that is, having love and understanding people.

\section{Master's in Professional Personal Development}

Correct and continuous self-development leads to success. There must be a self-development to be ahead of the world, always up to date and be the role of self-development in every profession. It is an integration by linking the society with various professions together so as to be able to lead the right way in the future world with increasing knowledge and experience and being up to date always. Everyone in every profession can achieve self-development. Therefore, every profession must have two main self-development principles: [5] [13]

1. Self-development according to general principles (Human resource development principles).

2. Self-development according to Buddhism.

\section{Self-Development Principles (Human Resource Development)}

Self-development principles for human resource development for increasing work efficiency, it is essential to develop human resources. One of the keys aims of human resource development is to improve the performance of individuals, groups, and organizations. Human resource development plays an important role in the performance of an individual and the work that should be accomplished in the work process. This will help to achieve the target results [6].
Human resources are the organization that have the most valuable resource, and helps to develop the characteristics of a person into a good and valuable resource of that organization. It helps to develop a person having knowledge and competence in the profession for which they are responsible, have a positive attitude, increase their creativity and outlook. Finally, acquiring these principles will help individuals to be able to adjust themselves to keep up with the changes of society and environment, adapt to the modern technology requirement. Therefore, individual development in the organization is essential to help the organization's success and achieve the organizational goal [7].

In this regard, in self-development or human resource development, VETS must be adhered to, which is the key to self-development or effective human resource development. VETS consisted of $\mathrm{V}=$ Vision, $\mathrm{E}=$ Education, $\mathrm{T}=$ Training, $\mathrm{S}=$ Study tour, described as follows: [8]

1. $\quad \mathrm{V}=$ Vision is the vision of the organization in the future, which is derived from wisdom, ideas, possible and consistent with goals and organizational obligations. The images are based on reality, credibility and mandatory to follow. This will make the organization to have a better condition than it is today.

2. $\mathrm{E}=$ Education is a method of human resource development that is necessary in one way because it increases the qualifications of human resources to have more knowledge due to technological changes adaptations. Knowledge which cannot be applied or used is obsolete. Therefore, it is imperative to send people to study further to advance the acquired knowledge, both nationally and internationally. We sometimes need to gain knowledge from abroad and this gained knowledge, abilities and experiences can be applied to the native country for himself as well as transmit to fellow beings to improve their selves. This imported knowledge may help to improve the performance of the department for higher efficiency.

3. 3. $\mathrm{T}=$ Training is to increase the knowledge, expertise, ability and change the attitudes, attitudes, feelings of the participants. So that they can perform their duties efficiently, able to fix flaws in current work and perform their work successfully in the future, as well as preparing people to take up a position of higher responsibility. All these tips are essential for effective human resource management.

4. $\quad \mathrm{S}=$ Study tour is an activity that will help us to do the best practice. Study tour has many advantages, example, it helps to observe the business in other departments, their office operations, process of working, etc. These observations will provide us ideas which can be applied in our office operations as well as various obstacles available in some departments.

\section{Principles of Human Resource Development in accordance with Buddhism}

Human resource development in accordance with Buddhism, there are many principles and teachings of the Lord Buddha, one of which is Iddhipada IV, which is important for getting success. The starting point for success is to develop the right people, as humans are not alien from the realities of nature, from the very basics, everything is consistent, nothing is broken. On this basis, we can apply 
different principles to our work environment. Based on correctness, we can decide whether the foundation is right, what Dharma we use now is going well, and all these are the principles of success [9].

In this regard, acquiring Dharma is considered as the ladder of success in the practice of all things, consisting of ambitiousness, satisfaction in the matter that we will do, persistence, perseverance and not give up in the undertaking of that business. In this regard, Wimangsa must continue to work on it, the four ladders to success as mentioned above [10] [11] [12].

1. Chanta (satisfaction) is satisfaction or motivation. This is something that can be created. If we study the job thoroughly, then we know how to work and achieve the purpose of that job very well. This will help to get job satisfaction by having a positive attitude.

2. Viriya (intention) is the indomitable intention. They are not afraid of obstacles and hardships when people know what is worthy of attainment. Although we know that the goal would be very difficult to reach as there were many obstacles, or it could only take a year, we should not give up, but try to perform it as a challenge and to overcome the difficulties to achieve the target goal.

3. Chitta (concentration) is a care or always concentrate on it, check how much work has been done, how much is left to be successful? What obstacles or flaws are there in work?, or that work is done smoothly. Chitta will be depending on me and persistence. If there is a lot of satisfaction, a lot of diligence, and a lot of attention, it is a direct focus on success quickly.

4. 4.Wimangsa (check) is the use of intelligence to contemplate, inspect, reason and examine even more slack, defect or failure in a business that has been known, tried, and thought to find solutions to improve.

5. If we follow the four main frameworks, namely 1) love of work, 2) perseverance in work, 3) mind focused on work, 4) analysis, synthesis, creativity, and development. We will be able to the development of work skills, not only for oneself but also for others for the betterment and progress of society in order to achieve the goals of the organization. This will make oneself, others and the organization to be more happy and prosperous.

\section{Holistic View of Human Resource Development according to Buddhism}

Self-development principles or human resource development is essential for increasing work efficiency the important aim of human resource development is to adhere to VETS, which is considered the key to self-development or human resource development. Therefore, self-development is essential for human resource development according to Buddhism. There is a doctrine of Lord Buddha, that is Iddhipada IV which is considered essential to achieve success in one's life. The starting point for success according to the Buddhist way of human resource development can be explained as follows:

\section{Vision and Chanta (satisfaction)}

For human resource development, it should start with a good vision to create a positive attitude of people to the organization to understand policy and command and help workers feel that they are part of the organization. Visualize the future that you want to be that is unique. There is a method of action that has a direction and scope that leads the organization towards its goals. So, when a good vision occurs, good attitudes will bring joy and satisfaction in practice, wanting to accomplish that good goal or work, guiding us to move towards a successful destination until the work results to efficiency.

\section{Education and Viriya (intention)}

For human resource development, this is considered important in education practice to acquire additional knowledge (Education) to get to know new academic. There are various techniques or methods for appropriate management of the organization. In addition, additional knowledge of the individual must be used, including perseverance (persistence) in the study of various academic research to be applied in practice. This can be enhanced with further education because education helps to develop thinking and education makes people intelligent and can also make people above the people.

\section{Training (training) and Chitta (concentration)}

Training (Training) is considered essential to develop human resources, to increase knowledge, expertise, ability to be able to perform their duties effectively in the workplace. The training is an enhancement of education to enhance various academic subjects other than systematic education by training or seminars on specific academic. This training will develop from painstaking education to the original cost. Therefore, the commitment (Chitta) to develop performance that takes care and attention in their work to be clearer.

\section{Study tour and Wimangsa (Check)}

Study tour in human resource development is to observe the work of other departments or organizations that will not lose the direction in the management of the organization. In this study visit, an individual will have the opportunity to see the actual performance of various organizations as well as inspect (Wimangsa) to find the strength and weakness of the departments or organizations. This study tour provides the chance to look the work environment and the knowledge gained from observation can be applied in the proper management of their own organization, after careful analysis, synthesis, creativity, development. Ultimately, it will lead to the development of skills in the work of oneself or of others to improve, to achieve the goals of organization. This will make oneself, others and the organization to be happier and more prosperous.

Therefore, it can be summarized in a diagram as a body of knowledge and application of human resource development as follows. 


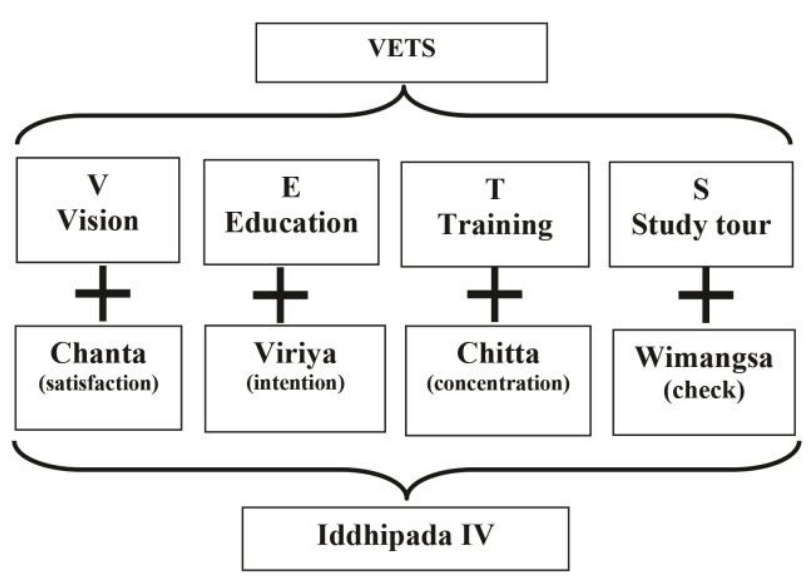

Fig. 1 Knowledge and application of human resource development: Phrakrukosolpariyattayanukij (Tharueti Rungchaiwitoon)

\section{Conclusion}

It is possible to develop ourselves to advance our career and collective work even though self-improvement is very difficult. Therefore, for the purpose of human resource development, the article identified the keys to personal development based on the philosophy of VETS, namely $\mathrm{V}=$ Vision is the vision of the organization in the future, which is derived from wisdom, ideas, possible and consistent with goals and organizational obligations. $\mathrm{E}=$ Education is a method of human resource development that is necessary in one way because it increases the qualifications of human resources to have more knowledge due to technological changes adaptations. $\mathrm{T}=$ Training is to increase the knowledge, expertise, ability and change the attitudes, attitudes, feelings of the participants. $S=$ Study tour is an activity that will help us to do the best practice. Study tour has many advantages, example, it helps to observe the business in other departments, their office operations, process of working. These symbols should be in conjunction with the principle of path of accomplishment; basis for success (Iddhipada IV), consisting of 1) Chanta (satisfaction) is satisfaction or motivation, 2) Viriya (intention) is the indomitable intention, 3) Chitta (concentration) is a mind focused on work, and 4) Wimangsa (check) is the use of intelligence to contemplate, inspect, reason and examine even more slack, defect or failure in a business that has been known, tried, and thought to find solutions to improve. Following these principles will lead human being to develop their skills in working for oneself or for others to get a better life or to achieve the target goals of their organizations. Finally, achieving these goals will lead to one's happiness and ultimately will result to a successful and prosperous organization.

\section{References}

[1] S. Panyaroj, Marketing strategy outside of the land. Bangkok: Petchrak, 2017.

[2] C. Meesamonai, Methods and techniques of human resource development,
Nonthaburi: Printing press, Sukhothai Thammathirat Open University, 2008.

[3] B. Phromsit, Organization Development for change, Bangkok: Message, 1997.

[4] S. Suthilertarun, Human behavior and personal development. Bangkok: Aksara Phiphat, 2000.

[5] Phradhampitaka (P.A. Payutto), Sustainable Development, Bangkok: Saha Thamik Company Limited, 1994.

[6] N. Khajornnant, Human Resource Management. Bangkok: SE-EDUCATION Publishing House, 2005.

[7] Phra Promkhunaporn (P. A. Payutto), Increasing efficiency in work, 8th ed. Bangkok: Mind Health, 2006.

[8] Phramaha Tharueti Virojano, Development of Self Potential for Better Work \& Happiness in Collaboration. Bangkok: Kesinee Publishing House, 2014.

[9] Phradhampitaka (P.A. Payutto). Dharma and work. 3rd ed. Bangkok: Phuthatham Foundation Publishing House, 2000.

[10] Phra Dharmakosajarn (Buddhadasa Bhikkhu), Happy work, Bangkok: Thammapha Printing Press, 2006.

[11] Mahachulalongkornrajavidyalaya University, Thai version of the Tipitaka the issue of MahaChulalongkornrajavidyalaya, Bangkok:

Mahachulalongkornrajavidyalaya Printing House, 1996.

[12] T. Puntharikwiwat, Buddhism and Thai society today. Bangkok: Withitat, 2002.

[13] S. Suthilertarun. Human behavior and personal development. Bangkok: Aksara Phiphat, 2000. 